\title{
CUSTOMER SATISFACTION IN NEPALESE CELLULAR NETWORKS
}

\author{
Rewan Kumar Dahal \\ *Lecturer, Nepal Commerce Campus, Minbhawan, TU
}

\begin{abstract}
Now a days identification of responsible factors that influence customer satisfaction is a key concern of marketers and research scholars and it will remain in future too. The purpose of the study was to identify the responsible factors that affect on customer satisfaction with cellular networks in Nepal and analyze them. Nepal Telecom and Ncell were taken as sample organizations where they occupy more than $94 \%$ of market share. The study was based on primary data collected through a structured questionnaire based on the judgmental sampling technique from 816 customers. It examined that price and service quality, brand and loyalty, corporate social responsibilities, network and coverage, and customer care and innovation were the responsible factors in the assessment of customer satisfaction with Nepalese cellular networks services. The study concluded that mobile service providers should concentrate upon the factors responsible on customer satisfaction and care of those factors that have significant influence on promoting customer satisfaction in Nepalese cellular networks industry.
\end{abstract}

Keywords: service quality - brand loyalty - social responsibilities - customer care - innovation.

\section{INTRODUCTION}

Customer satisfaction as an experience-based evaluation made by the customers by comparing the actual level of service obtained with that of their expectations. It is not a universal phenomenon and they do not enjoy the same service experience by consuming a commodity, service or idea due to variations of their needs, objectives and past experiences that influence their expectations (Saha et al. 2016). The unique combination of product features, services, and relationships of company should satisfy its customers' needs better than the competitors (Atkinson et al., 2014). Achieving and sustaining success by satisfying customers in today's hyper-competitive marketplace 


\section{0}

is an ultimate challenge for any company and business leader especially inservice industries like mobile telecommunication services.

The mobile network market in Nepal is relatively new yet the growth is much faster in comparison to other industries. The operators are enthusiastic to promote quality of services for customer satisfaction at present and near the future. All of them compete to grab customers by providing wide range of services based on customers demand. Markets are becoming more international, dynamic and customer-driven. Customers are demanding more variety, better quality and service, including both reliability and faster delivery. The companies should look for factors to attract, retain and satisfy their customers. In response to ongoing changes in the operating environment of cellular network industry, managers of telecom companies to stay in the competition and offering their services at acceptable levels, benefit from new techniques of management in their organizations (Khanmohammadi et al. 2015). Many studies notice that higher customer satisfaction means higher product quality and higher willingness to purchase the product (share of wallet) and a satisfied customer positively affects the profitability of the company.

Therefore, this study tries to find the answer of: what are the major factors that affect customer satisfaction in cellular networks industry in Nepal? To assess the issues, the objective of the study is to examine strength of the most influencing factors that affect customers' satisfaction and initiate some discussions in this regard.

\section{LITERATURE REVIEW}

Customer satisfaction is closely related with fair pricing on product or a service that leads to customer loyalty towards organization (MartinConsuegra et al. 2007). Both price level and price fairness influence on customer satisfaction (Hermann et al., 2007). Telecommunications services are undifferentiated products and therefore, mobile phone subscribers will be willing to pay for services only when they are satisfied, otherwise, they will switch to another operator (Lommeruda \& Sorgard 2003). Service quality is a comparison of perceived expectations of a service with perceived performance. Customers' perception is widely varied in accordance with the communication quality, call service, facilities, price, customer care and service provider's attributes (Paulrajan \& Rajkumr 2011). Customer service quality is a significant source of distinctive competence and often considered a key success factor in sustaining competitive advantage in 
service industries (Palmer 2001). Customer service can also be viewed as a system of activities that comprises customer support systems, complaint processing, speed of complaint processing, ease of reporting complaint and friendliness when reporting complaint (Kim, Park \& Jeong 2004). Furthermore, promises and commitments develop long term relationship and maintain customer loyalty (Sanchez \& Iniesta 2004) that lead better customer satisfaction.

Customer satisfaction generally depends on wider array of facilities for the customers (like easy recharge, easy utility bills payments, more friends and families (FNFs), customer care, higher speed in internet service etc.) offered by the marketers (Saha et al. 2016). Product differentiation and customers' facilities can be used as powerful tool of competitive advantage adopted by organizations for offering products to the customers that satisfy individual customer's needs (Saha et al. 2016). The brand image of the company is expected to have a positive relationship towards the customer expectations, satisfaction and loyalty (Martensen et al. 2000). Gupta (2002) found the empirical evidence between corporate reputation and competitive advantage for the firms by successfully differentiating it from competitors. It takes precedence in the services sector, especially with regards to those providing services with little differentiations and ones competing in aggressive conditions, for example, the telecommunications sectors (Santouridis \& Trivellas 2010).

Organizational societal and environmental image is a valuable intangible capital that is hard to imitate, and it can help an organization to achieve a sustainable and superior social performance. The image is expected to have a positive relationship towards the customer expectations, customer satisfaction and loyalty of customers to the company (Rahman, 2016). Corporate reputation and social responsiveness have significant competitive advantages (Gupta 2002). Network quality as one of the relevant factors in terms of evaluating service performance quality in determining the overall customer satisfaction (Rahman et al. 2011). Studies have shown that quality reflects the customers' expectations about a product or service (Leisen \& Vance 2001) and the service performance quality as the consumers' judgment about a firm's overall excellence or superiority (Parasuraman, Zeithaml \& Berry 1988). According to Leisen and Vance (2001) service performance quality helps to create the necessary competitive advantage by being an effective differentiating factor. 
Innovativeness satisfies customers by converting the invention or idea into product/service and improved firm value at acceptable risk (Dotzel et al. 2013). It influences customer satisfaction and customer retention from end user perspective (Salunke et al. 2013) and includes process innovation; customization; competitiveness. Technology and information facilitate innovation in competitive markets (Sood \& Tellis 2009) and improvisation, modification, augmentation or transformation of existing channels of trade using technology can reduce transaction costs that lead better customer satisfaction (Rodríguez-Pose \& Crescenzi 2008).

\section{Conceptual Framework and Hypotheses}

This study is guided from the stakeholders' theory and focuses on customers, specifically treating them well and managing for their interests, helps a firm create value along several dimensions and is therefore good for firm performance (Bosse, Phillips \& Harrison 2008). The conceptual framework of the study consists of seven major constructs that influence cell phone users' satisfaction such as price and service quality, friendly and responsive service, facilities and effective communication, brand and loyalty, corporate social responsibilities, network and coverage, and customer care and innovation among all as observed from the literature. The structural representation of the customer satisfaction presented in Figure 1.

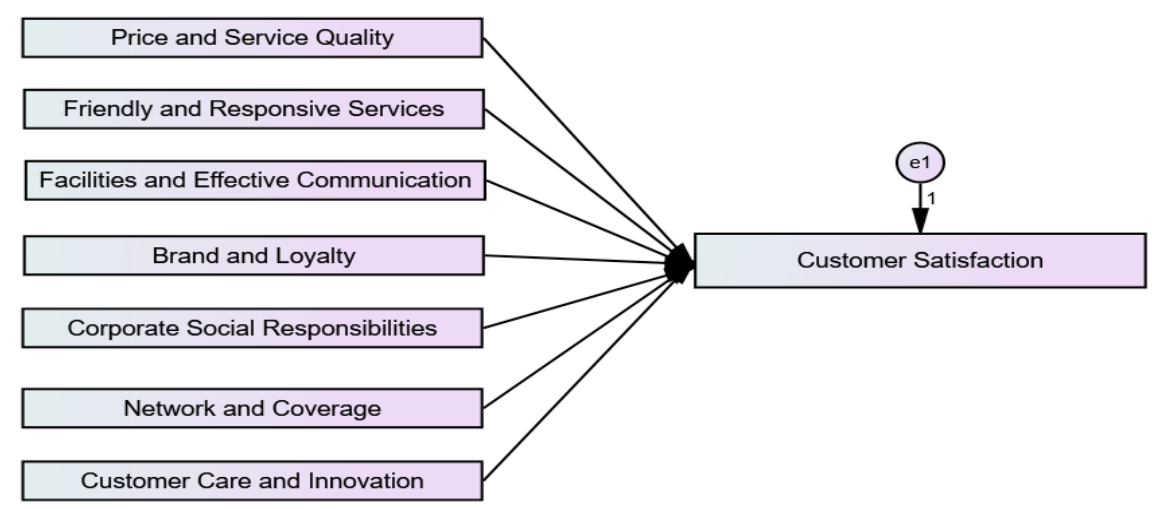

Figure 1: Conceptual framework of the study 
The conceptual framework leads to the following hypotheses:

H1: Price and service quality positively and significantly affect customer satisfaction.

H2: Friendly and responsive services positively and significantly affect customer satisfaction

H3: Facilities and effective communication positively and significantly affect customer satisfaction.

H4: Brand and loyalty positively and significantly affect customer satisfaction.

H5: Corporate social responsibility positively and significantly affects customer satisfaction.

H6: Network and coverage positively and significantly affect customer satisfaction.

H7: Customer care and innovation positively and significantly affect customer satisfaction.

\section{METHODOLOGY}

The study applied quantitative research strategy and used primary data. The data were collected through structured questionnaire survey. The population of the study comprised all the global system for mobile communication (GSM) customers of Nepal Telecom and Ncell since they occupy approximately $94 \%$ of the total market share. The study employed judgmental sampling technique because there was no evidence of active and the dead SIM card issue with sample companies. Targeted respondents of the study were: universities faculties, post graduate students, service holders, business persons, freelancers etc. who are living in different provinces and use GSM networks. A Sampling plan was used as proposed by Krejcie and Morgan's (1970), Bowerman et al. (2004) and ensured at least 385 respondents of each sample organization.

The questionnaire designed for customers' survey consisted of 48 items and organized into three sections. The first section asked for demographic / general information of the respondents and included 7 questions. The second section requested for customer satisfaction in various dimensions based on literature and included 33 questions. The third section asked for the overall satisfaction and included 8 questions. The last two sections focused on the study variables and series of close ended questions were composed in order to get appropriate information from the respondents. All survey items of the study 


\section{CUSTOMER SATISFACTION IN NEPALESE CELLULAR NETWORKS}

variables were measured with a 6-point Likert-type scale with $1=$ strongly disagree; $2=$ disagree; $3=$ slightly disagree; $4=$ slightly agree; $5=$ agree; $6=$ strongly agree. The 6-point scale was chosen because it does not include the ambivalent middle rating.

The questionnaires distributed through two ways: online survey and field survey. An online survey was done to MBA/MBS passed out students in last five years who are working at different part of Nepal by using data base provided by different colleges/universities. Total of 300 respondents were approached during 30 days period of March/April 2019. 112 responses were received from the online survey and recorded in SPSS for further analysis. On the other hand, a field survey was conducted and distributed in Tribhuvan, Kathmandu, Pokhara and Purbanchal Universities' MBS/MBA students and their faculties. The distribution was for 1,000 questionnaires and 728 were collected during 30 days of March/April 2019. From collected questionnaires, 24 questionnaires were rejected and 704 questionnaires were valid and recorded. Therefore, the total valid questionnaires were 816 which used in this study for analysis.

Reliability assessment was done by using Cronbach's alpha ( $\alpha=$ $0.907)$ and average inter-item correlation coefficient $(r=0.227)$ of 33 test items. Despite having ideal values, Cronbach's alpha also analyzed if item deleted. None of the item was found to delete. Thus, all 33 test items retained in the study. Table 1 presented the analytical result for the reliability statistics of each construct.

Table 1: Reliability statistics

\begin{tabular}{lcccc}
\hline \multicolumn{1}{c}{ Construct } & $\begin{array}{c}\text { Cronbach's } \\
\text { Alpha }\end{array}$ & $\begin{array}{c}\text { Average } \\
\text { inter-item } \\
\text { correlation }\end{array}$ & Name of the items & $\begin{array}{c}\text { No of } \\
\text { items }\end{array}$ \\
\hline $\begin{array}{l}\text { Price and service quality } \\
\begin{array}{l}\text { Friendly and responsive } \\
\text { services }\end{array}\end{array}$ & 0.647 & 0.389 & VAR_8, 9, 10 & 3 \\
$\begin{array}{l}\text { Facilities and effective } \\
\text { communication }\end{array}$ & 0.717 & 0.383 & VAR_11, 12, 15, 20 & 4 \\
$\begin{array}{l}\text { Brand and loyalty } \\
\begin{array}{l}\text { Corporate social } \\
\text { responsibility }\end{array}\end{array}$ & 0.605 & 0.278 & VAR_13, 14, 16, 21 & 4 \\
$\begin{array}{l}\text { Network and coverage } \\
\begin{array}{l}\text { Customer care and } \\
\text { innovation }\end{array}\end{array}$ & 0.820 & 0.303 & VAR_17, 18, 19, 22, 26 & 5 \\
\hline
\end{tabular}


The reliability statistics showed that four constructs had good values of alpha i.e. 0.7 or higher as suggested by Nunnally (1993) and three constructs had acceptable values of alpha i.e. 0.6 or higher as suggested by McKinley et al. (1997). In addition, all the constructs except network and coverage had good average inter-item correlation coefficient and fallen in the ideal range of 0.15 to 0.50 as suggested by Clark and Watson (1995). The study had adequate sample size since the Kaiser-Meyer-Olkin (KMO) value of 0.908 from 33 test items was greater than threshold value of 0.5 as recommended by Kaiser (1974). The significant value of Bartlett's test of sphericity (8703.311, $\mathrm{df}=528, \mathrm{p}=0.000$ ) indicated that the variables had some correlations to each other.

\section{ANALYSIS AND RESULTS}

This study was the customer evaluation of Nepalese mobile telecommunication service in terms of whether that has met their needs and expectations. To accomplish the objectives of the study, primary data were collected through structured questionnaire from 816 mobile phone users of Nepal Telecom and Ncell. The customers were 430 (52.7\%) from Nepal Telecom and 386 (47.3\%) from Ncell. As per the sample framed, the occupational background of the respondents was: students (53.9\%), service holders $(42.2 \%)$, business person $(2.6 \%)$ and freelancer (1.3\%). The study ensured almost equal participation of male and female, having with different age groups and from all 7 provinces of Nepal. The study showed that around $45 \%$ of Nepalese cell phone subscribers used both companies' services. With respect to connection type, more than $80 \%$ subscriber preferred pre-paid service, $10 \%$ preferred post-paid and about $10 \%$ used both post-paid and prepaid services. Nearly $7 \%$ Nepalese customers have fewer years of experience (less than 5 years) on mobile phone service.

This study examined the results of developing and testing the constructs by comparing the theoretical measurement model against reality, as represented by sample. A standard multiple regression was performed between overall customer satisfaction as the dependent variable with price and service quality, friendly and responsive services, facilities and effective communication, brand and loyalty, corporate social responsibilities, network and coverage, and customer care and innovation as independent variables. Table 2 showed the model summary and Table 3 showed analysis of variance of the model. The adjusted multiple correlation was significantly different from zero $(\mathrm{F}=158.441$, $\mathrm{p}>.001$ ) and $57.5 \%$ of the variation in the dependent variable was explained by the set of independent variables. Table 4 and Figure 2 reported overall model of the study. 
Table 2: Model summary of customer satisfaction

\begin{tabular}{|c|c|c|c|c|}
\hline Model & $\mathrm{R}$ & R Square & Adjusted R Square & $\begin{array}{l}\text { Std. Error of the } \\
\text { Estimate }\end{array}$ \\
\hline & 0.761 & 0.579 & 0.575 & 0.44575 \\
\hline Predictors: & \multicolumn{4}{|c|}{$\begin{array}{l}\text { (Constant), Price and service quality, Friendly and responsive } \\
\text { services, Facilities and effective communication, Brand and loyalty, } \\
\text { Corporate social responsibilities, Network and coverage, Customer } \\
\text { care and innovation }\end{array}$} \\
\hline Dependent & \multicolumn{4}{|c|}{ ariable: $\quad$ Customer satisfaction } \\
\hline
\end{tabular}

Table 3: ANOVA result of customer satisfaction

\begin{tabular}{lccccc}
\hline Model & Sum of squares & df & Mean square & F & Sig. \\
\hline Regression & 220.365 & 7 & 31.481 & 158.441 & 0.000 \\
Residual & 160.542 & 808 & 0.199 & & \\
\hline Total & 380.907 & 815 & & & \\
\hline Dependent variable: & Customer satisfaction & & \\
\hline Predictors: & (Constant), Price and service quality, & Friendly \\
& and responsive services, Facilities and effective \\
& communication, Brand and loyalty, Corporate social \\
& responsibilities, Network and coverage, Customer care \\
& and innovation \\
\hline
\end{tabular}

Table 4: Regression coefficients of overall customer satisfaction

\begin{tabular}{lcccccccc}
\hline Model & $\begin{array}{c}\text { Unstandardized } \\
\text { Coefficients } \\
\text { B }\end{array}$ & $\begin{array}{c}\text { S.E } \\
\end{array}$ & $\begin{array}{c}\text { Standardized } \\
\text { coefficients } \\
\text { Beta }\end{array}$ & t-value & Sig. & $\begin{array}{c}\text { Part } \\
\text { corr. } \\
\text { sq. (sr2) }\end{array}$ & $\begin{array}{c}\text { RIF } \\
\text { Vemarks } \\
\text { on } \\
\text { hypothesis }\end{array}$ \\
\hline $\begin{array}{l}\text { (Constant) } \\
\text { Price and } \\
\text { service quality }\end{array}$ & 0.521 & 0.114 & & 4.580 & 0.000 & & & - \\
$\begin{array}{l}\text { Friendly and } \\
\text { responsive } \\
\text { services }\end{array}$ & -0.003 & 0.022 & 0.097 & 3.493 & 0.001 & .0064 & 1.488 & Accepted \\
$\begin{array}{l}\text { Facilities } \\
\text { and effective } \\
\text { communication }\end{array}$ & 0.028 & 0.026 & 0.031 & 1.079 & 0.281 & .0006 & 1.589 & Rejected \\
$\begin{array}{l}\text { Brand and } \\
\text { loyalty }\end{array}$ & 0.182 & 0.029 & 0.193 & 6.347 & 0.000 & .0210 & 1.779 & Accepted \\
$\begin{array}{l}\text { Corporate social } \\
\text { responsibilities }\end{array}$ & 0.194 & 0.023 & 0.231 & 8.611 & 0.000 & .0841 & 1.376 & Accepted \\
$\begin{array}{l}\text { Network and } \\
\text { coverage }\end{array}$ & 0.090 & 0.019 & 0.126 & 4.824 & 0.000 & .0121 & 1.314 & Accepted \\
$\begin{array}{l}\text { Customer care } \\
\text { and innovation }\end{array}$ & 0.333 & 0.026 & 0.368 & 12.576 & 0.000 & .0824 & 1.644 & Accepted \\
\hline
\end{tabular}

Dependent variable: Customer Satisfaction

Regression equation: $Y=\beta_{0}+\beta_{1} X_{1}+\beta_{2} X_{2}+\beta_{3} X_{3}+\beta_{4} X_{4}+\beta_{5} X_{5}+\beta_{6} X_{6}+\beta_{7} X_{7}+\varepsilon$ 


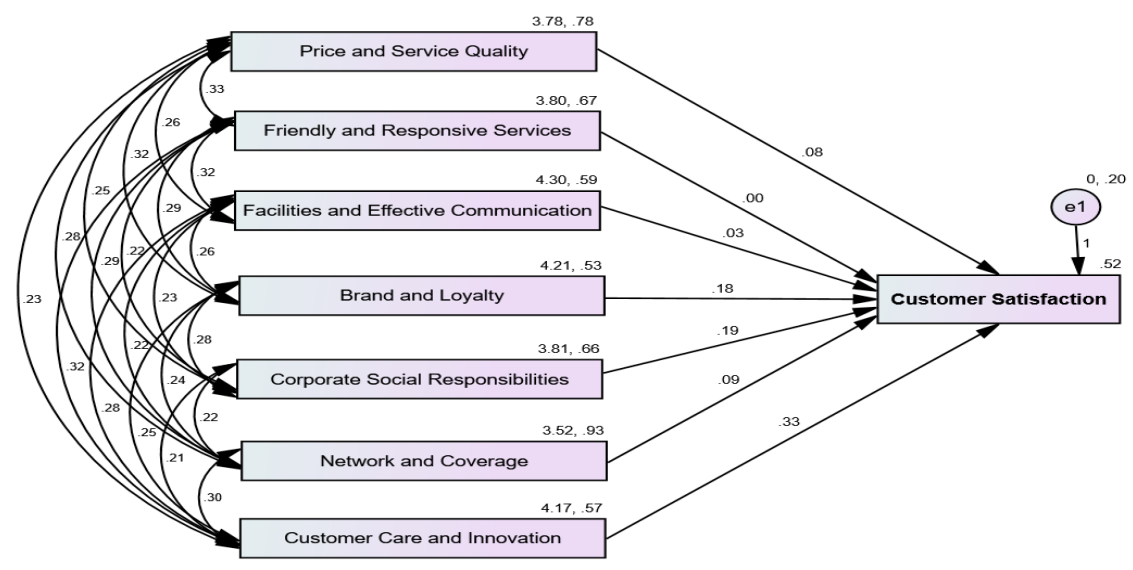

Figure 2: The regression model

Regression equation for the study, $Y=\beta_{0}+\beta_{1}$ Price and service quality $+\beta_{2}$ Friendly and responsive services

$+\beta_{3}$ Facilities and effective communication $+\beta_{4}$ Brand and loyalty

$+\beta_{5}$ Corporate social responsibilities $+\beta_{6}$ Network and coverage

$+\beta_{7}$ Customer care and innovation $+\varepsilon$

Customer satisfaction, $\mathrm{Y}=0.521+0.075$ Price and service quality -0.003 Friendly and responsive services +0.028 Facilities and effective communication +0.182 Brand and loyalty +0.194 Corporate social responsibilities +0.090 Network and coverage +0.333 Customer care and innovation $+\varepsilon$

As presented in Table 4 and Figure 2, all the independent variables except friendly and responsive services, and facilities and effective communication were found to be uniquely and significantly contribute to the prediction of customer satisfaction in Nepalese mobile telecommunication services. The main contributor independent variables were price and service quality $\left(\mathrm{sr}^{2}=0.0064, \mathrm{t}=3.493, \mathrm{p}=0.001\right)$, brand and loyalty $\left(\mathrm{sr}^{2}=0.0210, \mathrm{t}=\right.$ $6.347, \mathrm{p}=0.000)$, corporate social responsibilities $\left(\mathrm{sr}^{2}=0.0841, \mathrm{t}=8.611, \mathrm{p}=\right.$ $0.000)$, network and coverage $\left(\mathrm{sr}^{2}=0.0121, \mathrm{t}=4.824, \mathrm{p}=0.000\right)$ and customer care and innovation $\left(\mathrm{sr}^{2}=0.0824, \mathrm{t}=12.576, \mathrm{p}=0.000\right)$. Five set of independent variables out of seven were significantly related to the dependent variable. The Table 4 also examined that there was no problem of multi-collinearity as the observed values were well below 10.0 for each variable. The study did not 
accept that the constructs friendly and responsive services $\left(\mathrm{sr}^{2}=-0.0001, \mathrm{t}=\right.$ $0.114, \mathrm{p}=0.909)$, and facilities and effective communication $\left(\mathrm{sr}^{2}=0.0006, \mathrm{t}=\right.$ $1.079, \mathrm{p}=0.281$ ) had significant contribution towards customers satisfaction in Nepalese mobile telecommunication services.

\section{DISCUSSION AND CONCLUSION}

Literature review of the study identified seven major constructs as the determinants of the customer satisfaction in mobile telecommunication service. Out of seven constructs, five constructs: price and service quality, brand and loyalty, corporate social responsibilities, network and coverage, and customer care and innovation were observed as determinant factors that affect customer satisfaction in Nepalese mobile telecommunication services. The study did not accept the factors: friendly and responsive service, and facilities and effective communication as the determinants of customer satisfaction in Nepalese mobile telecommunication services though they were significant on the various previous studies (Kim, Park \& Jeong 2004, Sanchez \& Iniesta 2004).

Studies showed that price perceptions directly influence satisfaction judgments as well as indirectly through perceptions of price fairness (Herrmann et al. 2007). In consistent with the past studies (Martin-Consuegra et al. 2007, Hermann et al., 2007, Saha et al. 2016), customer satisfaction with Nepalese mobile telecommunication service was closely related with fair price, service quality and service reliability $(\beta=0.097, \mathrm{P}=0.001, \mathrm{AVE}=0.462)$. In the line of the previous studies (Martensen et al. 2000, Gupta 2002, Santouridis \& Trivellas, 2010, Moreira, Silva \& Mountinho 2017), brand image and loyalty ( $\beta$ $=0.193, p=0.000, \mathrm{AVE}=0.286$ ) had significant effect on customer satisfaction with Nepalese mobile telecommunication services. The brand image and loyalty were shaped mainly by: recommending products, price tolerance, trust, entertainment, and brand image.

Business is a part of society; social responsiveness of service provider creates positive soft corner in the inner mind of the customer and leads greater satisfaction. This study proved that 'corporate social responsibilities' was one of the major determinants of customer satisfaction $(\beta=0.231, p=0.000$, AVE $=0.408)$ with Nepalese mobile telecommunication services. Signal quality and network coverage have always been essential criteria for selecting mobile telecommunication service providers. Surveys have shown that both signal quality and network coverage affect consumer's satisfaction positively and the image of the company (Woo \& Fock 1999). In consistent with such previous 
studies, the factor 'network and coverage' was one of the significant factors $(\beta=0.126, p=0.000, \mathrm{AVE}=0.614)$ of customer satisfaction of Nepalese mobile telecommunication services too. Customer care and innovation satisfy customers by converting the invention or idea into product/service and improved firm value at acceptable risk (Dotzel et al. 2013). So, the factor 'customer care and innovation' was one of the significant factors $(\beta=0.368, p=0.000$, AVE $=0.359$ ) of customer satisfaction of Nepalese mobile telecommunication services having with the highest importance.

In conclusion, the study enriches to the literature by providing some insight into the benefits associated with exploring factors that affect customer satisfaction in Nepalese cellular networks industry. As per the stakeholder theory's guideline, the study supports to treat them well and manage for their interest, helps a firm to create values along several dimensions.

\section{LIMITATIONS AND IMPLICATIONS}

It was very difficult to survey the research exhaustively. So, this study cited representative research rather than attempting to be exhaustive. The reliability of the findings may be contingent on the number of participants could have been enhanced further by a larger sample. A larger sample size for the analytical survey would have augmented the validity and generality of the findings. The findings of this study provide helpful guidelines for Nepalese mobile telecommunication industry in understanding key drivers and offer valuable information regarding strategic areas in the field of customer satisfaction.

\section{REFERENCES}

Atkinson, A.A., Kaplan, R.S., Matsumura, E.M., Young, S.M. \& Kumar, G.A. (2014). Management accounting information for decision making and strategy execution, (6th ed.). New Delhi: Pearson Education, Inc.

Bosse, D. A., Phillips, R. A. \& Harrison, J. S. (2008). Stakeholders, reciprocity and firm performance. Strategic Management Journal, 30: 447-456. http://dx.doi.org/10.1002/smj.743.

Bowerman, B.L., O'Connell, R.T. \& Orris, J.B. (2004). Essential business statistics. 3rd ed. New York: McGrawHill.

Clark, L. A. \& Watson, D. (1995). Constructing validity: Basic issues in objective scale development. Psychological Assessment, 7(3): 309319. 
Dotzel, T., Shankar, V. \& Berry, L. L. (2013). Service innovativeness and firm value, Journal of Marketing Research, 50(2): 259-276.

Gupta, S. (2002). Strategic dimensions of corporate social responsibility as sources of competitive advantage via differentiation $(\mathrm{PhD}$ dissertation). Temple University, USA.

Herrmann, A., Xia, L., Monroe, K. B. \& Huber, F. (2007). The influence of price fairness on consumer satisfaction: An empirical test in the context of automobile purchases. Journal of Product \& Brand Management, 16(1): 49-58.

Kaiser, H. F. (1974). An index of factorial simplicity. Psychometrika, 39: 31-36.

Khanmohammadi, M., Mohammadi, M. \& Mehdizadeh, N. (2015). The feasibility of implementing the balanced scorecard - case study: nationwide provincial telecom companies. International Business Research, 8(8): $118-128$.

Kim, M., Park, M. \& Jeong, D. (2004). The effects of customer satisfaction and switching barrier on customer loyalty in Korean mobile Telecommunication services. Telecommunications Policy, 28:145159.

Krejcie, R. \& Morgan, D. (1970). Determining sample size for research activities. Educational \& Psychological Measurement, 30: 607610.

Leisen, B. \& Vance, C. (2001). Cross-national assessment of service quality in the telecommunication industry: Evidence from the USA and Germany. Managing Service Quality, 11(5): 307 - 317.

Lommeruda, K. E. \& Sorgard, L. (2003). Entry in telecommunication: Customer loyalty, price sensitivity and access prices. Information Economics and Policy, 15: 55-72.

Martensen, A., Kristensen, K. \& Gronholdt, L. (2000). Customer satisfaction measurement at post Denmark: results of application of the European customer satisfaction index methodology. Total Quality Management, 11(7): 1007-1015.

Martin-Consuegra, D., Molina, A. \& Esteban, A. (2007). An integrated model of price, satisfaction and loyalty: An empirical analysis in the service sector. Journal of Product \& Brand Management, 16(7): 459-468. 
McKinley, R. K., Manku-Scott, T., Hastings, A. M., French, D.P. \& Baker, R. (1997). Reliability and validity of a new measure of patient satisfaction with out of hours' primary medical care in the United Kingdom: development of a patient questionnaire. British Medical Journal, 314(7075): 193-198.

Moreira, A., Silva, P. M. \& Moutinho V. M. (2017). The effects of brand experiences on quality, satisfaction and loyalty: an empirical study in the telecommunications multiple-play service market. Innovar, 27(64): 23-38. doi: 10.15446/innovar. v27n64.62366.

Nunnally, J. C. (1993). Psychometric theory (3rd ed.). New York: McGrawHill.

Palmer, A. (2001). Principles of service marketing. New York: McGrawHill.

Parasuraman, A., Zeithaml, V. A. \& Berry, L. L. (1988). SERVQUAL: A multiple-item scale or measuring consumer perceptions of service quality. Journal of Retailing, 64(1): 12-40.

Paulrajan, R. \& Rajkumr, H. (2011). Service quality and customer preference of cellular mobile service providers. Journal of Technology Management and Innovation, 6(1): 38-45.

Rahman, M.H. (2016). Factors affecting customer satisfaction in mobile telecommunication industry in Bangladesh. Business, Management and Education, 12(1): 74-93.

Rahman, S., Haque, A. \& Ahmad, M. (2011). Choice criteria for mobile telecom operator: Empirical investigation among Malaysian customers. International Management Review, 7(1): 50-57.

Rodríguez-Pose, A. \& Crescenzi, R. (2008). Mountains in a flat world: Why proximity still matters for the location of economic activity. Cambridge Journal of Regions, Economy and Society, 1(3): 371388.

Saha, N.K., Islam, M.R. \& Hoque, A.U. (2016). Factors affecting customers' satisfaction of mobile phone subscribers: an empirical study on mobile telecommunication industry in Bangladesh. International Journal of Business and Management, 11(6): 252-261.

Salunke, S., Weerawardena, J. \& McColl-Kennedy, J.R. (2013). Competing through service innovation: the role of bricolage and entrepreneurship in project-oriented firms. Journal of Business Research, 66(8): 1085-1097. 
Sanchez, M. N. \& Iniesta, M. A. (2004). The structure of commitment in consumer-retailer relationships: conceptualization and measurement. International Journal of Service Industry Management, 15(3): 230-249.

Santouridis, I. \& Trivellas, P. (2010). Investigating the impact of service quality and customer satisfaction on customer loyalty in mobile telephony in Greece. The TQM Journal, 22(3): 330-343. https://doi. org/10.1108/17542731011035550.

Sood, A. \& Tellis, G. J. (2009). Do innovations really pay off? Total stock market returns to innovation, Marketing Science, 28(3): 442-456.

Woo, K.S. \& Fock, H. K. Y. (1999). Customer satisfaction in the Hong Kong mobile phone industry. The Service Industries Journal, 19(3): 162-174. 